\title{
ПАМ' ЯТЬ I ДОКУМЕНТИ ПРО РЯТУВАННЯ ЄВРЕЇВ УКРАЇНИ В ПЕРІОД ГОЛОКОСТУ: МІЖ МІФАМИ ТА ФАКТАМИ
}

\section{РОЗДІЛ 3. РЯТУВАННЯ ЄВРЁ̈В ПІД ЧАС ГОЛОКОСТУ}

Стаття присвячена одному з малодосліджених і міфологізованих аспектів історії Голокосту - проблемі рятування євреїв у часи Другої світової війни. Незважаючи на широкий масив джерельної бази, яка, по суті, і продукує низку хибних узагальнень щодо історій порятунку євреїв від знищення нацистами, оскільки грунтується на спогадах тих, хто пережив Голокост, історики стикаються із складністю інтерпретаціі і достовірності иих матеріалів. Специфіка використання наративів вимагає особливо ретельного наукового аналізу та зіставлення отриманих даних з іншими джерелами інформації.

Фактично дослідники звернулися до теми порятунку євреїв України в період Голокосту лише в пострадянський період. Нетривалість людської пам'яті є причиною великих розбіжностей між інформацією, яку можна було б отримати одразу по завершенню подій Другої світової війни і через двадиять, n'ятдесят, а тим більше сімдесят років. Проте спогади очевидиів, рятівників і порятованих, інтерв'ю у вигляді відео-чи аудіозаписів у пропонованій статті доповнені низкою документальних джерел, що зберігаються в різних архівних установах України.

У статті проаналізовано деякі з існуючих міфів щодо порятунку євреїв неєврейським населенням України в часі Голокосту, зокрема міф про антисемітські настрої українців, про безкорисливість рятівників тощо. Для спростування міфу про антисемітські настрої українців, передусім у Західній Україні, розглянуто регіональний аспект рятування, з’ясовано розподіл українських Праведників народів світу за областями і регіонами країни. Оперуючи кількісними даними, доведено особливий статус Biнницької області, яку виділено в окремий регіон. Варто зазначити, що для порівняння взято лише тих рятівників, яких офіційно визнано Яд Вашем, тобто присвоєно звання «Праведник народів світу», але у статті наведено історії й інших рятувань, зазвичай невдалих, оскільки саме матеріали судових справ німецьких окупантів проти місиевих мешканців збереглися в архівах.

Розглядаючи приклади рятування євреїв на окупованій території України, доходимо до висновків щодо основних мотивів людей, які ризикували не лише своїм власним життям, а (що траплялося частіше) життам своїх 
рідних. Наведено приклади рятування євреїв членами подружніх національно змішаних пар, їхніми рідними, а також людьми, які мали романтичні почуття чи дружні стосунки. Природними виглядають історії порятунку єврейського населення представниками релісійних громад.

Ключові слова: Голокост, Праведники народів світу, рятування, врятовані, рятівники євреїв, очевидиі подій, міф, усна історія.

\section{Специфіка джерельної бази вивчення історій рятування}

Очевидно, що Голокост є одним із найкраще досліджених явищ історії і з огляду на виявлені та опубліковані історичні документи, спогади, і наявну історичну літературу. Проте серед різних аспектів історії Голокосту проблема рятування від знищення нацистами євреїв є найменш дослідженою і найбільш міфологізованою.

Розглядаючи питання міфологізації цієї проблеми, ми будемо оперувати поняттям «Рятівник євреїв під час Голокосту». Під цю дефініцію підпадають як «Праведники народів світу», так і ті люди, щодо яких є грунтовні докази про рятування євреїв, які можуть бути визнані історичною наукою.

Міфи про рятування євреїв під час Голокосту пов'язані насамперед зі специфікою джерельної бази цієї проблеми. Білоруський дослідник історії Голокосту Євген Розенблат справедливо пише:

На відміну від багатьох аспектів теми Голокосту, які мають відображення в документальних джерелах, вивчення проблеми надання допомоги євреям у роки німецької окупації практично повністю грунтується на використанні наративних джерел (спогадів тих, хто пережив Голокост і матеріалів усної історії). Ця ситуація зрозуміла: в німецьких документах фіксувалися тільки невдалі спроби порятунку євреїв, які закінчувалися знищенням рятівників, їх сімей та євреїв, які переховувалися, а радянські органи та підрозділи не вели цілеспрямованої роботи зі збирання інформації про факти порятунку євреїв. Окремі випадки надання допомоги євреям згадуються в свідченнях, записаних Надзвичайною державною комісією із встановлення та розслідування злочинів німецько-фашистських загарбників та їх спільників (НДК) ${ }^{1}$.

Отже, спогади очевидців подій, рятівників та врятованих є найбільш інформативним джерелом вивчення проблеми. Але сам характер так званої усної історії (Oral History) визначає необхідність особливо ретельного наукового аналізу отриманої інформації,

${ }^{1}$ Див.: Евгений Розенблат, «Спасение евреев Беларуси в годы Холокоста: некоторые теоретические аспекты темы», у Праведники народов мира Беларуси: живые свидетельства Беларуси, сост. Кузьма Козак та ін. (Минск: И. П. Ловинов, 2009), 55. критичного ставлення до неї та порівняння з іншими джерелами інформації. Крім того, сьогодні, через сім з половиною десятиліть після закінчення Другої світової війни, в живих залишилося дуже мало свідків Голокосту. У кращому разі можна говорити про осіб, які були дітьми під час війни та могли бути здебільшого лише помічниками своїм рідним у ризикованій справі рятування євреїв. Частіше за все дослідники зараз мають справу з родинними історіями, що збереглись у пам'яті дітей та онуків.

У цьому контексті цінним джерелом є свідчення, зафіксовані на папері, аудіо- чи відеоносіях різними організаціями в рамках певних проєктів або зібрані окремими дослідниками. Серед них одним із найбільших є зібрання інтерв’ю, записаних за ініціативою Стівена Спілберга. Заснований видатним кінорежисером Фонд Шоа зберігає 53 тисячі відеосвідчень про Голокост. Доступ до цього величезного ресурсу є і в Україні завдяки діяльності Інституту візуальної історії та освіти Фонду Шоа в Україні (університет Південної Каліфорнії, США) ${ }^{2}$.

Вивченням Голокосту у Східній Европі взагалі та на території України зокрема займається французький дослідник і священник Патрік Дебуа. 32004 р. він започаткував збір відеоінтерв'ю свідків Голокосту - представників неєврейського населення. У результаті численних експедицій по всіх регіонах України П. Дебуа та очолювана ним організація «Яхад-ін Унум» (Франція) зібрали близько 1,5 тис. інтерв’ю свідків Голокосту, серед яких є й відомості про рятування євреїв ${ }^{3}$.

Важливий матеріал для вивчення історії рятування євреїв під час Голокосту дають документальні фільми, побудовані на відеозаписах інтерв’ю врятованих ${ }^{4}$. Відеоінтерв’ю щодо подій Голокосту на території України (а також Білорусі, країн Балтії, Росії) використовував для створення Антології документальних фільмів «Голокост у СРСР» ізраїльський кінорежисер Борис Мафцир. Зокрема, до фільму «За

\footnotetext{
${ }^{2}$ Див.: «Заснований Стівеном Спілбергом Фонд Шоа зберігає 53 тисячі відеосвідчень про Голокост», дата звернення 22 грудня, 2019, https://hromadskeradio.org/programs/zustrichi/ Голокост", дата звернення 22 грудня, 2019 , https://hromadskeradio.org/programs/zustrich
zasnovanyy-stivenom-spilbergom-fond-shoa-zberigaye-53-tysyachi-videosvidchen-pro-golokost.

${ }^{3}$ Див.: О. Патрик Дебуа, «Холокост при помощи пуль», дата звернення 22 грудня, 2019, http:// www.un.org/ru/holocaustremembrance/paper16.shtml; Андрій Уманський, упор., Розслідування Голокосту від куль: навчальний посібник, пер. з англ. Денис Шаталов (Дніпро: Інститут «Ткума»,

2019).

${ }^{4}$ Див.: «Те, кто остался в живых. История Сергея Сушона», YouTubeVideo, 45:54, розміщено «yadvashemrussian», 28 березня 2012, https://www.youtube.com/watch?v=rDBnT5yU-_M.
} 
Ністру» включені відеоматеріали щодо подій Голокосту в румунській зоні окупації, на території України

У 2019 р. у межах спеціального проєкту Українського інституту вивчення Голокосту «Ткума» в Дніпрі було створено фільм «Праведники», присвячений рятівникам євреїв Дніпропетровської області ${ }^{6}$.

Поки що недооцінений дослідниками ресурс щодо історії Голокосту та рятування євреїв - соціальні мережі, в яких інколи розміщуються інтерв'ю та спогади очевидців тих подій, записані здебільшого ї молодшими родичами і друзями. Зрозуміло, що будь-яка інформація із соціальних мереж потребує ретельної наукової перевірки.

Важливу інформацію щодо рятування євреїв під час Голокосту можна почерпнути в державних архівах України, а також у центрах вивчення Голокосту: в архіві Українського інституту вивчення Голокосту «Ткума», Музею «Пам'ять єврейського народу та Голокост в Україні» (м. Дніпро), Українського центру вивчення Голокосту (м. Київ), у регіональних музеях і центрах вивчення Голокосту у Львові, Одесі, Харкові, Чернівцях тощо.

Формат статті не дозволяє широко розглянути джерела з історії рятування євреїв під час Голокосту. Лише зауважимо, що на тлі слабкої документальної бази феномену рятування на більшій частині України надзвичайно цікавий масив архівних документів можна почерпнути, зокрема, з матеріалів судових процесів німецьких окупантів у Львові проти місцевих мешканців - українців і поляків, яких окупаційна влада звинувачувала в переховуванні євреїв. Серед таких справ, наприклад, справа Стефана Цироха і Ольги Коваличин із обвинувачення в переховуванні євреїв ${ }^{7}$; подібні справи зі звинувачення Петра Куліка, Романа Дабровського, Йозефа Ясинського ${ }^{8}$; Гната Барабача і Миколи Лутія ${ }^{9}$ та ін.

Проте підкреслимо, що ці унікальні документи відображають події саме в дистрикті «Галичина» і механічна екстраполяція подібних історій на інші окупаційні зони України не є коректною.

\footnotetext{
${ }_{5}^{5}$ Див.: «По следам неизвестного Холокоста. Документальный проект Бориса Мафцира», дата звернення 22 грудня, 2019, http://www.holocaustinussr.com/about-films-ru/.

${ }^{6}$ Див.: «Праведники. 2019. Документальний фільм», фільм липня 2019, YouTubeVideo, 25:58, розміщено «YevhenTitarenko», 29 липня 2019, https://www.youtube.com/watch?v=oWPDAhxJXIO.

7 Див.: Державний архів Львівської області (ДАЛО), ф. Р. 7, оп. 1, спр. D1230.

8 ДАЛО, ф. Р. 77 , оп. 1, спр. 847.

${ }^{9}$ ДАЛО, ф. Р. 77 , оп. 1, спр. 791.
}

\section{Факти, схожі на міфи, і міфи, що не базуються на фактах}

Насамперед зауважимо, що загальноприйнятого визначення поняття «міф» наразі не існує $\epsilon^{10}$. Використовуючи поняття «міф», ми не вживаємо його як синонім неправди чи вигадки, натомість розуміємо міф як сформоване уявлення певної соціальної чи національної групи, певної спільноти про явища та події, що мали місце в історії та порізному сприймаються різними групами людей сьогодні (безумовно, під впливом національної міфології) та певною мірою сакралізуються. При цьому міф маємо відрізняти від історичної пам'яті ${ }^{11}$.

Можна назвати чимало міфів, пов'язаних з історією Другої світової війни, які ми залишимо поза рамками нашої статті.

Якщо розглядати сучасні міфи саме про рятування євреїв під час Голокосту, то вони існують у різних спільнотах - i серед сучасних українців, поляків, і серед ізраїльтян. Деякі з цих міфів подібні, інші - протилежні; багато з них підтверджуються чи спростовуються фактами. Ще більше міфів, очевидно, вже не будуть співвіднесені з документальними матеріалами, бо останні просто не збереглися.

Наведемо приклади деяких із таких міфів.

1. Міфи про кількість рятівників і врятованих євреїв (наприклад, у сучасному польському суспільстві все більш «популярними» стають історії про активну участь поляків у рятуванні євреїв; створюють відповідні музеї та музейні експозиції, знімають фільми, пишуть книжки. Натомість спогади про співучасть частини поляків у Голокості сприймаються в суспільстві досить болісно).

2. Міф про антисемітські настрої українців (передусім - у Західній Україні), які переважно, мовляв, були антисемітськи налаштовані та нищили євреїв більш активно, ніж німецькі підрозділи (на відміну від сходу України - де, за деякими міфами, радянське підпілля боролося проти нацистів і, зокрема, допомагало євреям).

3. Міф про безкорисливість українських рятівників євреїв (нагадаємо, що відсутність матеріальної винагороди є умовою отримання звання «Праведник народів світу»).

4. Міф про особливу роль християнського духівництва в рятуванні євреїв (а також міф про роль священників-антисемітів у нацьковуванні українців на євреїв).

\footnotetext{
${ }_{10}$ Див.: Данило Судин, «Національні міфи в сучасній Україні», Україна модерна: міжнародний інтелектуальний часопис, 12 грудня, 2014, дата звернення 22 грудня, 2019, http://uamoderna.com/ $\mathrm{md} /$ sudyn-national-myths
}

11 Див.: Судин, «Національні міфи в сучасній Україні». 
5. Міф про провідну роль української інтелігенції, української еліти в рятуванні євреїв.

6. Міф про тотальну ненависть німецьких солдатів, німців взагалі до євреїв, $\mathrm{i}$ - «протилежний» за змістом міф про німецьких рятівників євреїв від українських вбивць.

Утім, фактом є те, що умови для порятунку євреїв на території України радикально відрізнялися від західноєвропейських. Українські терени перебували під владою тоталітарних режимів, ще й за умов війни. Мовчазна згода з насильством могла бути зумовлена і радянською спадщиною «одностайного» засудження «ворогів народу», «другорядності» цінності людського життя. Глибокий травматичний слід у суспільній свідомості, який залишив своїм громадянам сталінський режим, помножувався на тотальну деморалізацію від катастрофи Червоної армії на першому етапі війни та швидкого наступу гітлерівських військ і захоплення ними величезних територій.

Тімоті Снайдер відніс територію України до «кривавих земель» ${ }^{12}$, де вбивство величезної кількості людей сприймалося буденно, через звичку до «банальності зла» - вислів, поширений завдяки книзі Ханни Арендт ${ }^{13}$. За таких умов людські та людяні почуття часто поступаються прагматичним міркуванням. Атмосфера насильства та заохочення до вбивств, помножена на антисемітизм частини населення та інші чинники, створили відповідні суспільні настрої сприйняття масового винищення євреїв як «норми» за умов нацистського «нового порядку». За деякими свідченнями, «якщо не брати до уваги купку шляхетних людей, християнські жителі міста з ентузіазмом брали участь у ганебних операціях полювання на євреїв, які проводилися німцями» ${ }^{14}$

3 іншого боку, відповідно до нацистської расової політики, українців - рятівників євреїв - очікувало найжорстокіше покарання, знищення самих рятівників та членів їх сімей. Навіть надання притулку євреям загрожувало тут смертною карою.

Разом із тим, принципові відмінності мали умови для рятування євреїв у різних регіонах України.

\footnotetext{
12 Див.: Тімоті Снайдер, Криваві землі: Європа поміж Гітлером та Сталіним (Київ: Грані-Т, 2011).

${ }_{13}$ Див.: Ханна Арендт, Банальність зла. Суд над Айхманом в Єрусалимі (Київ: Дух і Літера, 2013).

14 Жанна Ковба, упор., Щоденник Львівського гетто. Спогади рабина Давида Кахане (Київ: Дух і літера, 2009), 200.
}

\section{Окремо про деякі міфи: міф про антисемітські настрої українців}

Ми вирішили розглянути регіональний аспект рятування, визначивши розподіл українських Праведників народів світу за областями і регіонами України (відповідно до сучасного адміністративнотериторіального поділу країни). Окремо ми виділили Вінницьку область, яка займає особливе місце в «регіональній картині» рятування. Це безпосередньо стосується згаданого нами міфу про антисемітські настрої українців, передусім - у Західній Україні. Відповідно до наших підрахунків складено таку таблицю.

Приналежність за регіонами Праведників народів світу з України

(аналіз здійснено на основі офіційної статистики Меморіалу Яд Вашем станом на 1 січня 2018 р.)

\begin{tabular}{|c|c|c|c|c|c|c|}
\hline $\begin{array}{c}\text { Закар- } \\
\text { паття та } \\
\text { Буковина }\end{array}$ & $\begin{array}{l}\text { Західна } \\
\text { Україна }\end{array}$ & $\begin{array}{c}\text { Північна } \\
\text { та Цен- } \\
\text { тральна } \\
\text { Украйна }\end{array}$ & $\begin{array}{l}\text { Вінницька } \\
\text { область }\end{array}$ & $\begin{array}{c}\text { Південна } \\
\text { Украйна }\end{array}$ & $\begin{array}{c}\text { Східна } \\
\text { Украйна }\end{array}$ & $\begin{array}{c}\text { Інші } \\
\text { території }\end{array}$ \\
\hline $\begin{array}{l}\text { Закарпат- } \\
\text { ська: } 24\end{array}$ & $\begin{array}{l}\text { Волин- } \\
\text { ська: } 116\end{array}$ & $\begin{array}{l}\text { Дніпропе- } \\
\text { тровська: } \\
69\end{array}$ & 516 & $\begin{array}{l}\text { AР Крим: } \\
27\end{array}$ & $\begin{array}{l}\text { Доне- } \\
\text { цька: } 55\end{array}$ & Білорусь: 2 \\
\hline \multirow[t]{7}{*}{$\begin{array}{l}\text { Черні- } \\
\text { вецька: } 9\end{array}$} & $\begin{array}{l}\text { Івано- } \\
\text { Франків- } \\
\text { ська: } 75\end{array}$ & $\begin{array}{l}\text { Житомир- } \\
\text { ська: } 221\end{array}$ & & $\begin{array}{l}\text { Запо- } \\
\text { різька: } 21\end{array}$ & $\begin{array}{l}\text { Луган- } \\
\text { ська: } 9\end{array}$ & Молдова: 2 \\
\hline & $\begin{array}{l}\text { Львівська: } \\
117\end{array}$ & $\begin{array}{l}\text { Кірово- } \\
\text { градська: } \\
49\end{array}$ & & $\begin{array}{l}\text { Миколаїв- } \\
\text { ська: } 81\end{array}$ & $\begin{array}{l}\text { Харків- } \\
\text { ська: } 87\end{array}$ & $\begin{array}{l}\text { Німеч- } \\
\text { чина: } 2\end{array}$ \\
\hline & $\begin{array}{l}\text { Рівнен- } \\
\text { ська:216 }\end{array}$ & $\begin{array}{l}\text { Київська } \\
\text { та м. Київ: } \\
221\end{array}$ & & $\begin{array}{l}\text { Одеська: } \\
163\end{array}$ & & Польща: 24 \\
\hline & $\begin{array}{l}\text { Тернопіль- } \\
\text { ська: } 170\end{array}$ & $\begin{array}{l}\text { Полтав- } \\
\text { ська: } 36\end{array}$ & & $\begin{array}{l}\text { Херсон- } \\
\text { ська: } 28\end{array}$ & & Росія: 5 \\
\hline & $\begin{array}{l}\text { Хмель- } \\
\text { ницька: } \\
178\end{array}$ & $\begin{array}{l}\text { Сумська: } \\
19\end{array}$ & & & & $\begin{array}{l}\text { Україна: } \\
1 \text { (регіон } \\
\text { невідомо) }\end{array}$ \\
\hline & & $\begin{array}{l}\text { Черкась- } \\
\text { ка: } 60\end{array}$ & & & & \\
\hline & & $\begin{array}{l}\text { Чернігів- } \\
\text { ська: } 16\end{array}$ & & & & \\
\hline \multicolumn{7}{|c|}{ Загалом } \\
\hline 33 & 872 & 691 & 516 & 320 & 151 & 36 \\
\hline
\end{tabular}

Розглядаючи цю таблицю, ми можемо побачити, що значна кількість випадків рятування євреїв зареєстрована на територіях, де проживало відносно багато поляків - як на території сучасної Польщі, так і на теренах Волинської, Луцької, Хмельницької, Житомирської областей.

Також бачимо, що, незалежно від регіону, найбільше Праведників налічується в місцях, де частка євреїв у населенні була відносно 
великою (Вінниця та інші західноукраїнські міста, містечка й села, а також Київ, Житомир, Одеса тощо), тож допомога сусідів, які мали досвід співжиття в довоєнні часи, відіграла значну роль у рятуванні євреїв під час Голокосту.

Абсолютна першість з кількості Праведників народів світу України належить сучасній Вінницькій області, де їх кількість становить майже п’яту частину від усіх українських Праведників (19,7\%). Це на 10\% більше, ніж кількість українських Праведників у восьми сучасних областях Південної та Східної України (включаючи Одеську область) та Криму разом. Цей факт потребує свого пояснення. Окрім наведених вище чинників, зауважимо, що саме на Вінниччині був поширений такий вид допомоги євреям, як організація їх переходу з німецької до румунської зони окупації, де було відносно більше шансів на виживання.

Ще ширшою є картина рятування євреїв мешканцями України, які не отримали звання «Праведник народів світу». Навіть на офіційному сайті Яд Вашем сказано: «Кількість Праведників у тій чи іншій країні не обов'язково свідчить про фактичну кількість історій рятування, а лише відображає ті випадки, про які відомо Яд Вашем» ${ }^{15}$.

Як ми вже зазначали, велика кількість таких маловідомих випадків мали місце на Західній Україні, де існували свої особливості в «механізмі» знищення євреїв та умов і можливостей їх рятування.

Унікальні ресурси для вивчення цього питання має Державний архів Львівської області, де зберігаються особливо важливі для нашої теми матеріали Спеціального суду при Німецькому суді у Львові дистрикту «Галичина» ${ }^{16}$.

Якщо на території Райхскомісаріату «Україна» українських рятівників євреїв часто розстрілювали на місці, то в дистрикті «Галичина» справи про рятування розглядав вищезазначений нацистський суд.

Серед документів за 1941-1944 рр. ми нарахували понад 40 справ щодо звинувачення жителів регіону в «переховуванні євреїв» ${ }^{17}$ або «в наданні притулку» ${ }^{18}$, «у сприянні втечі євреїв із гетто у Львові» ${ }^{19}$. Такий досить великий обсяг матеріалів щодо людей, які рятували

15 Див.: «Праведники народов мира. Статистика», дата звернення 23 грудня, 2019, http://www. yadvashem.org/yv/ru/righteous/statistics.asp.

${ }^{16}$ Див.: ДАЛО, ф. Р. 77, оп. 1. Документи написані польською і німецькою мовами, окремі сторінки написані українською.

17 Див.: ДАЛО, Ф. Р. 77 , оп. 1, спр. 309, 366, 504, 592, 654, 661, 735, 758, 759, 791, 800 та ін.

${ }^{18}$ Див.: ДАЛО, Ф. Р. 77 , оп. 1, спр. 1111

${ }^{19}$ Див.: ДАЛО, Ф. Р. 77, оп. 1, спр. 1358. євреїв (чи намагалися їх рятувати), але яким не присвоєно звання «Праведників народів світу» і навіть не розглядалися Комісією Яд Вашем, є черговим аргументом шодо необхідності вивчення феномену рятівників євреїв - ширшого поняття, ніж «Праведники народів світу».

Зауважимо, що згадані архівні матеріали дають можливість відтворити певні характеристики ставлення окупаційної німецької влади не тільки до євреїв, які підлягали реєстрації, повній ізоляції, а згодом винищенню, а й до українців, поляків та інших представників місцевого неєврейського населення. Красномовним прикладом ставлення нацистів до поляків та українців, і навіть до симпатиків гітлерівського режиму, може бути історія поляка Яна Петришина ${ }^{20}$.

\section{Міф про безкорисливість рятівників євреїв}

Про мотиви надання надзвичайно ризикованої допомоги євреям йтиметься нижче. Тут же зазначимо, що майже в кожному випадку рятування євреїв у тому чи іншому вигляді поставав матеріальний чинник.

Відомо, що отримання матеріальної винагороди за рятування євреїв під час Голокосту не відповідає принципам, за якими Яд Вашем присвоює звання «Праведник народів світу». Безумовно, було чимало випадків, коли рятівники надавали допомогу переслідуваним євреям без жодної користі. Натомість важливо зауважити, що переховування людей протягом довгого періоду, багатьох місяців, а інколи й років, завжди має «економічну складову», пов'язану з необхідністю насамперед закупівлі харчів. «Як випливає зі спогадів, - зазначав Ярослав Грицак, - вижити могли тільки євреї, які мали гроші - бо треба було втримати і самих себе, й заплатити тим, хто тебе переховував» ${ }^{21}$.

Наявні документи (тут ми розглядаємо матеріали Державного архіву Львівської області) надають відомості про дуже різні обставини матеріальних та фінансових «розрахунків» євреїв зі своїми польськими та українськими рятівниками.

«Томрук Хведь признався, що була в нього жидівка майже через цілий тиждень..., і що він давав їй їсти, за це вона йому дала 2 метри [нерозбірливо] і пошила дві сорочки для родини Томрука Хведя» ${ }^{22}$. За

\footnotetext{
20 Див.: ДАЛО, ф. Р. 77, оп. 1, спр. 502, 574.

21 Ярослав Грицак, «Як українці переховували євреїв», дата звернення 23 грудня, 2019, https:// www.obozrevatel.com/society/15436-yak-ukraintsi-perehovuvali-evreiv.htm.
}

22 ДАЛО, ф. Р. 77, оп. 1, спр. 759, арк. 6 зв. 
матеріалами судової справи, «Томрука Хведя і 2 метри [нерозбірливо] забрано і разом доставлено до Німецької Жандармерії у Радехові» 23.

Українці Ігнат Барабач і Микола Лутій переховували в Золочеві свого знайомого Соломона Гельфера. На слідстві М. Лутій говорив: «Гельфер вручив мені 4 метри матеріалу на пошиття одягу, 1 жіночу велику хустку, а також суму у 90 злотих. У квітні 1944 р. згаданий єврей дав мені суму у 500 злотих. Зважаючи на те, що, як вже зізнався, був дуже бідним і маю родину, яка складається з дружини і 3 дітей, у квітні 1944 р. не мав що давати їсти ані своїй родині, ані цьому євреєві. Сказав йому, що має щось зробити. Згаданий єврей пішов до мого сусіда Барабаша Ігната з Красносельця і від нього приніс 25 кг ячменю, а також 5 кг гречки. Після цього той же єврей у червні 1944 р.: пішов до Барабаша удруге і приніс від нього 25 кг ячменя і 25 кг картоплі. Через те, що по будинках почали проводитись обшуки на предмет виявлення партизанів, я боявся, що того єврея у мене можуть знайти, тому пішов сам до гміни та зізнався, що у мене є єврей. Прийшло військо і єврея Гельфера Соломона було забрано з льоху, який знаходиться у моїй стодолі, мене ж залишили вдома. Як я пізніше довідався, єврей той звідти утік, а мене на другий день військо заарештувало та привезло до Золочева. Коли того єврея за кілька днів повторно зловили, саме тоді він зізнався, що я його переховував» ${ }^{24}$.

До цих красномовних матеріалів варто додати, що вони датуються 20-22 червня 1944 р. - лише за місяць до того, як німецькі війська залишили Львів (що відбулося 27 липня 1944 р.).

Міхаліна Мерська, полька, «переховувала у своїй квартирі у Львові на вулиці Падеревського № 12 2-х єврейок і 3-х євреїв з 2.6.1943 р. до 3.2.1944 р., беручи від них кошти на утримання та за переховування у сумі 3000 злотих щомісяця.Тут хочу пояснити, що цих євреїв утримувала не у квартирі, у своєму підвалі. Робила це тому, що не мала 3 чого жити» ${ }^{25}$

Розалія Сурма (з села Верхоли, біля Грабової, пов. Кам'янка Струмілова), неписьменна, зізналася в утриманні чотирьох євреїв у своєму обійсті до 23 жовтня 1943 р.: «Ці євреї обіцяли дати мені 50 злотих, якщо їх утримуватиму протягом двох тижнів. На що я погодилася, але з таким наміром, що як прийде їх трохи більше, дам знати у відділок

${ }^{23}$ ДАЛО, ф. Р. 77, оп. 1, спр. 759, арк. 6 зв.

24 ДАЛО, Ф. Р. 77 , оп. 1, спр. 791, арк. 20 зв.

${ }_{25}$ ДАЛО, ф. Р. 77, оп. 1, спр. 851, арк. 26.
Української поліції у Грабові» ${ }^{26}$. Згаданий намір німецький суд визнав «сумнівним», і полька була засуджена ${ }^{27}$.

Еврей Зігмунд Едель (Zygmund Edel) переховувався у Львові в поляків Стефанії Ціпік (Stefania Ciepik), Станіслави Білик (Stanisłava Biłyk) та Coфiї Пакіт (Zofia Pakiet) «за оплату 400 злотих щомісяця» ${ }^{28}$. Очевидно, що ці гроші мали покривати витрати на харчування.

Часто бувало, що рятівники не вимагали від євреїв конкретної суми грошей, а питали про їх можливості. За ці гроші господарі купували продукти харчування для себе та тих, кого переховували ${ }^{29}$.

I, нарешті, архівні матеріали містять відомості про випадки безкорисливого рятування євреїв. Зокрема, влітку 1944 р. у ході розслідування нацистами справи рятування єврей Альтер Сафро свідчив:

Як єврей у травні місяці 1943 р. утік з єврейського гетто і до цього моменту переховувався у католиків... Я... пішов до свого знайомого Домбровського Романа [Dąbrowskiego Romana], у Львові на вулиці Личаківській, 19. Його знав з ловецьких часів з періоду спільної роботи на олійні та підтримував його під час голоду, бо був заможнішим, а він бідним. Давав йому харчі і гроші. Домбровського просив, аби мене сховав, і він милосердно погодився, коли я вже не мав жодних засобів для життя, даючи мені харчі та житло ${ }^{30}$.

Донька Альтера Сафро, Маня Годжін, яка теж знайшла притулок у Р. Домбровського, підтверджувала: «Виходячи з бункеру, не мали жодних речей та грошей. Я разом із чоловіком не платили Домбровському грошей за наше переховування, бо той, переховуючи батька, переховував і нас» ${ }^{31}$.

У німецьких судових матеріалах знаходимо приклади, коли в ході справ поляки та українці, яких звинувачували в переховуванні євреїв, за допомогою адвокатів домагалися свого виправдання.

Аргументами для цього могла бути їх «необізнаність» у єврейському походженні тих, кого переховували. Зокрема, під час розгляду справи щодо єврея М. Рінгера, який перебував на квартирі в польки І. Бариляк, суд дійшов висновку, що «Бариляк Ірена насправді не знала, що познайомилась з євреєм і навіть не припускала, що Рінгер

\footnotetext{
${ }^{26}$ ДАЛО, ф. Р. 77, оп. 1, спр. 735, арк. 5 зв.

${ }_{27}$ ДАЛО, ф. Р. 77 , оп. 1 , спр. 735 , арк. 6.

${ }^{28}$ ДАЛО, Ф. Р. 77, оп. 1, спр. 1227, арк. 13.

${ }^{29}$ Див.: ДАЛО, Ф. Р. 77, оп. 1, спр. 504, арк. 25-26.

${ }_{30}$ ДАЛО, Ф. Р. 77, оп. 1, спр. 847, арк. 14.

${ }_{31}$ ДАЛО, Ф. Р. 77, оп. 1, спр. 847, арк. 21 зв.
} 
був євреєм. Рінгер навмисне ввів в оману Бариляк, представляючись їй Пьотрем Рогушем, прагнучи мати свою особисту єврейську вигоду» ${ }^{32}$

В іншому випадку двірник Пьотр Фінк, затриманий 28 січня 1944 р. за утримання дитини, Максимілліана Туртельтауба, - онука єврейки з Відня, свідчив, що він «був упевнений, що німецький закон не передбачає переслідування євреїв німецького походження. Якби це знав, ніколи б єврейську дитину до своєї квартири не прийняв» ${ }^{33}$ Німецький суд все ж засудив Пьотра, але визначив щодо дружини і доньки поляка: «проведеними слідчими діями не вдалося довести вину Фінк Катажини і Фінк Хелени, що нібито вони були співучасницями в переховуванні єврея» ${ }^{34}$.

Деякі прохання адвокатів про помилування на перший погляд виглядають кумедно, але насправді містять досить принизливі характеристики звинувачуваних. Наприклад, адвокат Адольф Фіда пише 15 липня 1944 р. генерал-губернатору в м. Краків:

Від імені засуджених до страти Ганчар Марії (Ganczar Maria) та Нахач Василя (Nahatsch Wasyl). Не беручи до уваги безгрішний життевий шлях та визнання провини з глибоким каяттям, шо виказується всіма можливими засобами, я прошу врахувати дуже низький рівень освіти засуджених. Вони народились та виросли на віддаленому хутоpi, не мали змоги отримати ніякої шкільної освіти. Обидва не знають грамоти, Нахач тільки-но навчився підписуватись своїм ім'ям під час військової служби за часів світової війни. Обидва мають дуже примітивний світогляд та тип мислення, типові екземпляри галицьких неосвічених сільських анальфабетів, які мають обмежене духовне життя $^{35}$. Ваша Високосте, вони не мали гадки про заборону переховувати євреїв ${ }^{36}$.

Зрозуміло, випадки виправдання українців та поляків, яких звинувачували в переховуванні євреїв, не були частими. За рятування євреїв платили своїм життям і безкорисливі доброчинці, і ті, хто намагався заробити на цьому гроші. Тільки в одному «Розпорядженні про боротьбу з замахами на німецьку справу відбудови у генерал-губернаторстві від 2.10.1943 р. судом поліції Безпеки і СД Галицької області» на смерть було засуджено «за переховування жидів» десять чоловік:

З2 ДАЛО, ф. Р. 77, оп. 1, спр. 1258, арк. 15.

${ }_{33}$ ДАЛО, Ф. Р. 77 , оп. 1 , спр. 904, арк. 8.

${ }_{34}$ ДАЛО, Ф. Р. 77, оп. 1, спр. 904, арк. 18.

35 ДАЛО, Ф. Р. 77, оп. 1, спр. 366, арк. 68.

${ }^{36}$ ДАЛО, Ф. Р. 77 , оп. 1, спр. 366, арк. 68-69.
Крушковська Марія уроджена Бобекова з Лембергу, П’ястун Міхал з Лембергу, Скомпський Казімеж з Лембергу, Ковальчик Здіслав з Лембергу, Суш Настя уроджена Дяченко з Руданець, Іжек Юлія з Лембергу, Слядовська Галина уроджена Клименєвська з Лембергу, Малявська Вікторія уроджена Вільчинська з Лембергу, Йозефек Броніслав з Лембергу, Йозефек Марія уроджена Сльовіч з Лембергу... ${ }^{37}$.

Окремі історії навіть у викладі німецьких судових документів виглядають особливо трагічно. Це стосується, зокрема, Володимира Корбецького (Wladimir Korbecki), який у період з листопада 1942 до травня 1943 рр. переховував «у своєму домі двох єврейок на ім'я Роза та Краус та трирічну дитину єврейки Краус. Від єврейок у перші дні після їх прийому він отримав 1700 злотих...» ${ }^{38}$. Судове рішення містить жорстокий вирок: «Обвинувачений, який не мав до цього часу судимостей, відповідно до § 4 б вказаної постанови має бути покараний єдиним передбаченим покаранням - стратою» ${ }^{39}$. Вирок було виконано: «Засуджений Володимир Корбецькі був розстріляний 7 березня 1944 року...» ${ }^{40}$.

Отже, рятування євреїв за платню (відшкодування витрат, або «для прибутку») мало кілька наслідків.

1. Інколи, коли гроші у євреїв закінчувалися, «корисливі рятівники» здавали їх нацистам або поліцаям на розправу і вірну смерть.

2. Інколи, коли «акції спасіння» розпочинались через корисливі мотиви, а у євреїв вичерпувалися матеріальні ресурси, рятівники виявляли кращі людські якості і продовжували допомагати, вже не отримуючи винагороди.

3. Навіть якщо єврея (або групу євреїв) рятували за гроші, це не означало меншого ризику для рятівників, яких нацисти карали так само, як і безкорисливих Праведників народів світу. Так, для певних людей переховування євреїв стало певним «бізнесом», на якому намагалися заробити у скрутні воєнні часи. Але ж і за виказування євреїв, за доноси на їх рятівників німці давали винагороду, і такий «спосіб заробітку» був більш безпечною справою. За умов існування цих двох протилежних «способів заробляння на євреях» свою роль відігравали, за спостереженням Я. Грицака, «людський страх і заздрість: “вона” переховує євреїв,

\footnotetext{
${ }_{37}$ Див.: Жанна Ковба, Людяність у безодні пекла. Поведінка місцевого населення Східної Галичини в роки “остаточного розв'язання єврейського питання» (Київ: Дух і літера, 2009), 200-201.

${ }^{38}$ ДАЛО, ф. Р. 77 , оп. 1, спр. 504, арк. 16 зв.

39 ДАЛО, ф. Р. 77 , оп. 1, спр. 504, арк. 40.

40 ДАЛО, ф. Р. 77, оп. 1, спр. 504, арк. 20.
} 
заробляє на цьому - а “ми” через це можемо постраждати, якщо, не дай Боже, німці виявлять, що ми знали і не донесли» ${ }^{41}$.

Варто зазначити ще один момент: видання євреїв було не просто «виявом лояльності» гітлерівському режиму, але й визначалося нацистськими законами й постановами та представлялося геббельсівською пропагандою як «чеснота» для суспільства і «моральний обов'язок» його членів. За умов викривленої тоталітарними системами суспільної свідомості та сплюндрованої моралі цей чинник робив справу рятування євреїв ще більш небезпечною.

Можна навести ще чимало прикладів різних міфів, які відбиваються у спогадах і родинних історіях; у відозвах відвідувачів музею «Пам'ять єврейського народу та Голокост в Україні», у фейсбуці тощо.

3 деякими міфами, стереотипами, і разом із тим - із бажанням знати історичну правду про своє місто та село і його історію співробітники інституту «Ткума» зіткнулися під час реалізації проєкту «Праведники». Цей великий проєкт передбачав найменування вулиць населених пунктів Дніпропетровської області іменами Праведників народів світу, які жили в цих містах і селах у період Другої світової війни та Голокосту. Нам спільно з обласною владою і місцевими органами влади пощастило сприяти перейменуванню на честь українських рятівників євреїв вулиць у 13 населених пунктах області, - подібного немає в жодному регіоні світу.

Детальніше про факти рятування євреїв можна говорити після критичного аналізу архівних матеріалів і ще більш критичного ставлення до спогадів та мемуарів.

\section{До питання про мотивацію рятування євреїв}

Приклади рятування євреїв на окупованій території України потребують з'ясування мотивів людей, які ризикували не тільки своїм власним життям, а й життям своїх рідних, дітей, надаючи допомогу переслідуваним євреям.

Чимало було випадків, коли люди намагалися врятувати євреїв членів своїх родин чи коханих.

Наприклад, українська дружина єврея Ісаака Шлимовича (ім'я жінки в документі відсутнє), яка в жовтні 1941 р. зустріла німецьку окупацію в селі Михайлівці Запорізької області, поліцаям «дитя на вбивство... не віддала», i, врешті, врятувала дитину від змішаного шлюбу ${ }^{42}$. Полька Антонія Хомчинська (Antonia Chomczinska) зі

${ }^{41}$ Грицак, «Як українці переховували євреїв».

42 Див.: Державний архів Запорізької області (ДАЗО), ф. Р. 1849, оп. 1, спр. 1.
Львова «впродовж декількох місяців приховувала чотирьох євреїв» у квартирі, де вона жила ${ }^{43}$. Коли поліція в червні 1943 р. затримала трьох євреїв, «одному з цих євреїв вдалось втекти з квартири за допомоги Хомчинської. 3 одним 3 цих євреїв Хомчинська напевно мала стосунки. Це виходить з одного листа Хомчинської, який було знайдено раніше» ${ }^{4}$. До речі, в ході слідства не вдалось «довести провину польки Антонії Хомчинської в укритті євреїв» ${ }^{45}$.

Відомо чимало прикладів, що свідчать про участь у порятунку не тільки одинаків-українців, а і груп людей, іноді достатньо великих. I. Альтман пише про те, як у кількох українських селах місцеві жителі зуміли укрити всіх євреїв: у селі Яруга на Поділлі вдалося заховати не лише місцевих жителів-євреїв, а й біженців; у селі Раковець Львівської області селяни переховували 33 єврейські сім’ї; у селі Благодатне Дніпропетровської області було врятовано 30 євреїв. І. Альтман підкреслює, що їх порятунок став можливим лише завдяки колективній підтримці решти жителів села ${ }^{46}$.

Слід зауважити, що подібні приклади не поодинокі. Арон Вайс у своїх спогадах розповідає, що мешканка західноукраїнського міста Борислав українка Юлія Матчишин для організації порятунку сім’ї Вайсів заручилася підтримкою іншої сусідки - польки пані Потенжної ${ }^{47}$.

В окупованому Запоріжжі українка Євдокія Купа переховувала дівчинку Марію Чапату, мати якої розстріляли гітлерівці. Щоб убезпечити дитину від загрози арешту і знищення, сусіди клопотали перед німецькою владою про видачу Марії паспорта як українці; четверо людей виступили як офіційні свідки (двох із них допитували), розуміючи, чим їм загрожує обман нацистів. Загалом про єврейську дівчину, яка переховувалася від гітлерівців, знали майже всі мешканці вулиці - кілька десятків людей; ніхто з них не видав Марію, а багато хто допомагав ${ }^{48}$.

Загалом, потребують подальшого з'ясування питання про «соціальний склад» рятівників євреїв, серед яких більшість становили

$\overline{43}$ ДАЛО, Ф. Р. 77, оп. 1, спр. 661, арк. 3.

${ }_{44}$ ДАЛО, Ф. Р. 77 , оп. 1, спр. 661 , арк. 3.

${ }^{45}$ ДАЛО, ф. Р. 77 , оп. 1, спр. 661, арк. 37.

${ }^{46}$ Див.: Илья Альтман, Холокост и еврейское Сопротивление на оккупированной территории СССР (Москва: Фонд «Холокост», 2002).

47 Див.: Особистий архів автора.

${ }^{48}$ Игорь Щупак, «Отношение украинского населения Запорожья к евреям во время войны 1941 1945 гг.», Запорожские еврейские чтения 1 (1997): 120-121. 
люди, які не належали до верхівки українського суспільства, його інтелектуальної еліти.

Відомі випадки, коли на допомогу євреям за критичних умов приходили службовці міських управ, а також німецькі офіцери, угорські солдати і навіть німецькі солдати та місцеві поліцаї, які брали участь у розстрілах євреїв ${ }^{49}$. Але, зрозуміло, такі приклади були нетиповими. Очевидно, що реалізація будь-яких наказів влади, ті або інші вчинки здійснюються конкретними людьми зі своїм особистим минулим і особистими симпатіями, чи то співробітники управ, чи то солдати, чи то українські поліцаї та ін. Безумовно, траплялись випадки, коли рятування євреїв було продиктовано душевним, людським поривом, прагненням надати допомогу жертвам нелюдської жорстокості нацистів. Піддавшись «першому пориву», часто надалі люди вже були змушені продовжувати смертельно небезпечну справу.

Натомість досить поширеними були випадки рятування євреїв українцями через релігійні переконання, християнське ставлення до гнаних та переслідуваних. Карел Беркгоф стверджує, що серед українців найбільше євреям допомогли баптисти і християни-євангелісти. «На самій тільки Волині, - пише історик, - вони, вочевидь, врятували сотні людей. Ці протестанти гадали, що їхня християнська віра не дозволяла їм чинити інакше». Крім того, використовуючи взаємні зв'язки між протестантськими громадами, вони «могли швидко переводити євреїв із однієї місцевості до наступної» ${ }^{50}$.

Значну кількість серед рятівників-священнослужителів становлять представники Української греко-католицької церкви. Тут слід згадати і «рядових» священників УГКЦ, серед яких блаженний священомученик Омелян Ковч, котрий заплатив життям за рятування євреїв; i, звичайно, величну постать митрополита Андрея Шептицького. Останній особисто врятував чимало євреїв, серед них - львівського рабина Давида Кагане, синів загиблого рабина Левіна Курта (Ісаака) і Натана. Митрополит залучив до рятування євреїв деяких українських священників, серед яких були його брат Климентій, архімандрит монахів Студійського уставу, а також ігуменя монастиря сестер-студиток Йосефа (Олена Вітер), преподобний Марко Стек та інші. Андрей Шептицький рятував усіх, кому він міг надати допомогу, передусім - дітей. Їм давали фальшиві довідки про хрещення,

${ }^{49}$ Щупак, «Отношение украинского населения Запорожья к евреям во время войны $1941-1945$ гг.».

50 Карел Беркгоф, Жнива розпачу. Життя і смерть в Україні під нацистською владою, пер. Тарас Цимбал (Київ: Критика, 2011), 95. українські імена, а потім розподіляли по жіночих та чоловічих монастирях і дитячих будинках. Деяким дітям студитські монахи допомагали перетинати румунський та угорський кордони. Загалом за допомогою митрополита Андрея Шептицького були врятовані близько 200 євреїв $^{51}$

Зауважимо, що А. Шептицькому досі не надано високого звання Праведника народів світу - через його вітання гітлерівської армії в перші дні після нападу Німеччини на СРСР, контакти з нацистськими високопосадовцями тощо (цьому присвячена досить багата історична література ${ }^{52}$ ). Ми вважаємо, що велич подвигу таких людей, як митрополит Андрей Шептицький, не потребує підтвердження чи схвалення навіть високою та поважною інституцією. Сам факт організації цілої системи допомоги жертвам нацистського геноциду силами церковної організації, пасторська настанова до церковних ієрархів щодо спасіння сотень приречених на загибель євреїв перетворили митрополита Андрея Шептицького на уособлення гуманізму в протистоянні людожерській політиці нацистів. Шевах Вайс, врятований разом із родиною під час Шоа українцями та поляками, колишній спікер Кнесету (парламенту) Ізраїлю та Посол Ізраїлю в Польщі, образно назвав А. Шептицького «українським Шиндлером» ${ }^{53}$.

51 Див.: Ігор Щупак, «Трагедія євреїв України», в Національне питання в Україні XX - початку XXI ст.: історичні нариси, ред. Валерій Смолій (Київ: Ніка-Центр, 2012), 419.

52 Див.: Bohdan R. Bociurkiw, «Sheptyts'kyi and the Ukrainian Greek Catholic Curch Under the Soviet Occupation of 1939-1941», y Morality and Reality. The Life and Times of Andrei Sheptyts'kyi, ред. Paul Robert Magocsi with the assistance of Andrii Krawchuk (Edmonton: Canadian Institute of Ukrainian Studies, University of Alberta, 1989), 101-123; Жанна Ковба, упор., Митрополит Андрей Шептицький. Докумении і матеріали: 1941-1944 (Київ: Дух і літера, 2003); Шиион Реялих, “иитро-

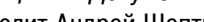
плит Андрей Шен 27 грудня, 2019, http://www.cerkva.od.ua/index.php?option=com_content\&task=view\&id=594\&ltem id=87; Шимон Редлих, «Моральные принципы в повседневной действительности: митрополит Андрей Шептицкий и евреи в период Холокоста и Второй мировой войны», дата звернення 27 грудня, 2019, http://www.jcrelations.net/\%D0\%A1\%D1\%82\%D0\%BE\%D1\%80\%D0\%BE\%D0\%BD\%D0\% B0.3180.0.html? L=7; Мирослав Маринович, «Постать Митрополита Шептицького у нелінійному просторі історичного часу», Проблеми історії Голокосту: науковий журнал 4 (2007): 81-87; Ігор Щупак, «Митрополит Андрей Шептицький: особистість та символ в історії», Проблеми історі Щупак, «Митрополит Андрей Шептицький: особистість та символ в історіі», Проблеми історіі
Голокосту: науковий журнал 4 (2007): 88-99; Тетяна Чайка, «Колаборація у "просторі смерті": до осмислення моральної колізії Митрополита Андрея Шептицького», Проблеми історії Голокосту: науковий журнал 4 (2007): 100-113; Жанна Ковба, «Вплив митрополита Шептицького на вірних у часи Голокосту», Проблеми історії Голокосту: науковий журнал 4 (2007): 127-151; Ковба, упор., Щоденник Львівського гепто; Жанна Ковба, Останній рабин Львова Єзекіїль Левін (Львів; Київ: Дух і Літера, 2009) та ін.

53 Шимон Редлих, «Шептицкий отрицал расистское мышление (интервью профессора Шимона Редлиха журналу “Тыгодник Повшехны” (Tygodnik Powszechny))", дата звернення 27 грудня, 2019, http://www.newswe.com/index.php?go=Pages\&in=view\&id=3690. 
Отже, серед тих, хто надавав допомогу євреям, були представники різних верств населення та різних спільнот, які керувалися різними мотивами.

1. Було чимало випадків, коли члени подружніх національно змішаних пар, їхні рідні рятували євреїв як своїх родичів. Сюди ж треба додати українців, поляків та інших, які відчували романтичні почуття, кохання до своїх обранців - представників єврейського народу. Хоча були й такі страшні випадки, коли матері видавали на смерть своїх дітей-«полукровок» або видавали своїх єврейських чоловіків та дружин. Тож тут маємо говорити про душевні якості людей-рятівників.

2. Колишні колеги євреїв по навчанню й роботі, сусіди, яких пов’язувало з євреями життя в довоєнні часи, допомагали через дружні почуття, товариські відносини. Були випадки, коли українці рятували тих євреїв, які колись їм надали допомогу у скрутні часи.

3. Українські підпільники та партизани інколи вбачали в допомозі євреям одну із форм Опору нацистському режиму.

4. Окремі люди, яких можна назвати нонконформістами та які не могли адаптуватися в суспільстві за панування нацистського режиму, через допомогу жертвам цього режиму намагалися протистояти насильству та таким чином психологічно самостверджуватися.

5. Християни, які рятували євреїв через свої релігійні переконання.

6. «Випадкові рятівники» - люди, які намагалися рятувати євреїв через раптовий душевний порив прийти на допомогу переслідуваним.

7. Були й корисливі мотиви надання допомоги євреям - намагання заробити гроші, отримати матеріальну вигоду від тих, кого рятували, про що вже йшлося вище.

У цілому слід підкреслити, що на захист євреїв під час Голокосту на окупованій території України не виступила жодна українська політична сила чи воєнна організація. Також і радянський уряд, який володів інформацією про винищення євреїв нацистами, не довів її до відома єврейського населення ${ }^{54}$. Не було декларацій, заяв, закликів до українського населення надати допомогу євреям ані з боку українського чи польського підпілля, ані з боку радянського уряду та підпорядкованих йому радянських партизанських загонів і радянського підпілля. Це відіграло свою трагічну роль у величезній кількості

54 Очевидно, це було зумовлено «інтернаціоналістською» складовою комуністичної ідеології, згідно з якою в радянському суспільстві не виділяли окремі національні групи, які мали особливу долю за певних історичних умов. Водночас той самий «інтернаціоналістський» підхід не завадив радянській владі організувати масову депортацію кримських татар чи німців Поволжя, коли це виходило із рішень сталінського керівництва СРСР. загиблих українських євреїв, яких нараховується півтора мільйона осіб з шести мільйонів усіх євреїв - жертв Голокосту.

Водночас історія Другої світової війни містить не тільки жахливі сторінки масових вбивств, а й приклади опору геноциду та рятування. Жоден із тих євреїв, яким було врятовано життя в період Голокосту, не могли сподіватися на спасіння без допомоги, яку ризикували надавати їм українці та представники інших народів нашої країни, які теж страждали від гітлерівської окупації.

Робота 3 дослідження історії українських рятівників євреїв під час Голокосту, фактів та міфів про рятування є важливим науковим і моральним завданням, бо надає позитивні приклади людської поведінки за нелюдських умов війни. Це особливо актуально для України сьогодні, коли наша країна стала об'єктом воєнної та інформаційної агресії.

Igor Shchupak

\section{MEMORY AND DOCUMENTS ON THE RESCUE OF JEWS IN UKRAINE DURING THE HOLOCAUST: BETWEEN MYTHS AND FACTS}

The article focuses on one of the unexplored and mythologized aspects of $\mathrm{Ho}$ locaust history - the problem of the rescue of Jews during the Second World War. Despite the wide array of sources, which in fact generates numerous false generalizations about the stories of the rescue of Jews from extermination by the Nazis, as based on the memoirs of those who survived the Holocaust - historians face the complexity of the interpretation and validity of these materials. The specifics of using narratives necessitate especially thorough scientific analysis and the comparison of data acquired with other sources of information.

In fact, researchers did not begin to explore the issue of the rescue of Jews in Ukraine during the Holocaust until the post-Soviet period. A lack of vital human memory in this connection has caused significant discrepancies and disagreements between information that could be obtained immediately after the Second World War and data acquired 20, 50, and more than 70 years later. However, the memoirs of eyewitnesses, rescuers and those rescued, and interviews in the form of video or audio recordings are supplemented in this article by many documentary sources housed in various archival institutions in Ukraine.

The present article analyzes some of the existing myths about the rescue of Jews by the non-Jewish population during the Holocaust, in particular myths about the anti-Semitic sentiments of Ukrainians, the unselfishness of rescuers, etc. In examining and refuting the myth of anti-Semitic sentiments of Ukrainians, first 
of all in western Ukraine, the regional aspect of rescue is considered, defined by the distribution of the Ukrainian Righteous among the Nations by regions of the country. Based on quantitative data, the special status of the Vinnytsia region is substantiated and identified as a distinct region. It should be noted that for purposes of comparison, this article only utilizes data on rescuers officially recognized by Yad Vashem, meaning they were given the designation "The Righteous Among the Nations". However, the article also contains stories of other rescue attempts, usually unsuccessful, based on the materials of the court cases of the German invaders against the locals, cases most commonly preserved in the archives.

Exploring examples of the rescue of Jews in the occupied territory of Ukraine, conclusions are drawn regarding the main motives of individuals who risked not only their own lives but the lives of their relatives (the latter more often). The article presents examples of the rescue of Jews by members of ethnically-mixed married couples, their relatives, as well as persons who had romantic sentiments for or friendships with Jews. Stories of rescue of the Jewish population by religious communities are also highlighted.

Keywords: Holocaust, Righteous among the Nations, rescue, Jews rescued, rescuers of Jews, witnesses of events, myth, Oral history.

\section{Bibliography}

Al'tman, Il'ya. Kholokost i yevreyskoye Soprotivleniye na okkupirovannoy territorii SSSR. Moskva: Fond «Kholokost», 2002.

Arendt, Khanna. Banal'nist' zla. Sud nad Aykhmanom v Yerusalymi. Kyyiv: Dukh i Litera, 2013.

Berkhof, Karel. Zhnyva rozpachu. Zhyttya i smert'v Ukrayini pid natsysts'koyu vladoyu. Pereklad Taras Tsymbal. Kyyiv: Krytyka, 2011.

Bociurkiw, Bohdan R. «Sheptyts'kyi and the Ukrainian Greek Catholic Curch Under the Soviet Occupation of 1939-1941.» Y Morality and Reality. The Life and Times of Andrei Sheptyts'kyi, ред. Paul Robert Magocsi with the assistance of Andrii Krawchuk, 101-123. Edmonton: Canadian Institute of Ukrainian Studies, University of Alberta, 1989.

Chayka, Tetyana. «Kolaboratsiya u «prostori smerti»: do osmyslennya moral'noyi koliziyi Mytropolyta Andreya Sheptyts'koho.» Problemy istoriyi Holokostu: naukovyy zhurnal 4 (2007): 100-113.

Gutman, Israel', i Naama Galil'. Katastrofa i pamyat'o ney. Perevod Zoya Kopel'man, Yakov Sinichkin. Iyerusalim: Yad Vashem, [b.g.].

Hrytsak, Yaroslav. «Yak ukrayintsi perekhovuvaly yevreyiv.» Data zvernennya 23 Hrudnya, 2019. https://www.obozrevatel.com/society/15436yak-ukraintsi-perehovuvali-evreiv.htm.
Koval', Mykhaylo. «Natsyst·s'kyy henotsyd shchodo yevreyiv ta ukrayins'ke naselennya (1941-1944 rr.).» Ukrayins'kyy istorychnyy zhurnal, no. 2 (1992): 25-32.

Kovba, Zhanna. Lyudyanist' u bezodni pekla. Povedinka mistsevoho naselennya Skhidnoyi Halychyny v roky «ostatochnoho rozv"yazannya yevreys'koho pytannya». Kyyiv: Dukh i litera, 2009.

Kovba, Zhanna. Ostanniy rabyn L'vova Yezekiyil' Levin. L’viv; Kyyiv: Dukh i Litera, 2009.

Kovba, Zhanna. «Vplyv mytropolyta Sheptyts'koho na virnykh u chasy Holokostu.» Problemy istoriyi Holokostu: naukovyy zhurnal 4 (2007): 127-151.

Kovba, Zhanna, upor. Mytropolyt Andrey Sheptyts'kyy. Dokumenty i materialy: 1941-1944. Kyyiv: Dukh i litera, 2003.

Kovba, Zhanna, upor. Shchodennyk L'vivs'koho hetto. Spohady rabyna Davyda Kakhane. Kyyiv: Dukh i litera, 2009.

Marynovych, Myroslav. «Postat' Mytropolyta Sheptyts'koho u neliniynomu prostori istorychnoho chasu.» Problemy istoriyi Holokostu: naukovyy zhurnal 4 (2007): 81-87.

Medvedovska, Anna. Holokost v Ukrayiny v suspilnyy dumtsi kintsya XX - pochatku XXI st. Disertatsiya na zdobuttya naukovogo stupenya kandidata istorichnih nauk. Dnipro, 2016.

Nakhmanovych, Vitaliy. «Babyn Yar: mistse pam'yati u poshukakh maybutn'oho.» U Babyn Yar: Istoriya i pam"yat', redaktory Vladyslav Hrynevych i Pavlo-Robert Magochiy, 313-335. Kyyiv: [b.v.], 2016.

Honcharenko, Olexiy. Do pytannia pro uchast' mistsevoho naselennia u poriatunku ievreiv na terytorii Rajkhskomisariatu Ukraina (1941-1944 rr.) Ukrains'kyj istorychnyj zhurnal [Ukrainian Historical Journal] 1(2010): $128-141$.

«O Pravednykakh.» Yad Vashem. Data zvernennya 22 Hrudnya, 2019. http://www1.yadvashem.org/yv/ru/righteous/about.asp.

Paldiel', Mordekhay. «Pravedniki narodov Mira v gody Kholokosta.» Data zvernennya 22 Hrudnya, 2019. https://www.yadvashem.org/ru/education/educational-materials/lesson-plans/righteous/righteous1.html.

«Po sledam neizvestnogo Kholokosta. Dokumental'nyy proyekt Borisa Maftsira.» Data zvernennya 22 Hrudnya, 2019. http://www.holocaustinussr.com/about-films-ru/.

«Pravedniki. 2019. Dokumental'nyy fil'm.» Fil'mLypen' 2018. YouTubeVideo, 25:58. Rozmishcheno «Yevhen Titarenko,» 29 lypnya 2019. https://www.youtube.com/watch?v=oWPDAhxJXI0. 
«Pravedniki narodov mira, 2018.» Yad Vashem. Data zvernennya 22 Hrudnya, 2019. http://www.yadvashem.org/yv/ru/righteous/faqs.asp.

«Pravednyky narodov myra. Statystyka.» Data zvernennya 23 Hrudnya, 2019. http://www.yadvashem.org/yv/ru/righteous/statistics.asp.

«Pravedniki narodov mira.» U Kholokost: Entsiklopediya, redaktor Uolter Lakor, soredaktor Yudit. T. Baumel', 490-491. Moskva: [b.i.], 2008.

Redlikh, Shimon. «Mitropolit Andrey Sheptitskiy i yevrei v period Kholokosta i Vtoroy mirovoy voyny.» Data zvernennya 27 Hrudnya, 2019. http://www.cerkva.od.ua/index.php?option=com_content\&task=view\&id $=594 \&$ Itemid $=87$.

Redlikh, Shimon. «Moral'nyye printsipy v povsednevnoy deystvitel'nosti: mitropolit Andrey Sheptitskiy i yevrei v period Kholokosta i Vtoroy mirovoy voyny.» Data zvernennya 27 Hrudnya, 2019. http://www.jcrelations.net/\% D0\%A1\%D1\%82\%D0\%BE\%D1\%80\%D0\%BE\%D0\%BD\%D0\%B0.3180 0.html? $\mathrm{L}=7$.

Redlikh, Shimon. Razom i narizno v Berezhanakh: Polyaky, yevreyi ta ukrayintsi, 1919-1945. Kyyiv: [b.v.], 2007

Redlikh, Shimon. «Sheptitskiy otritsal rasistskoye myshleniye (interv’yu professora Shimona Redlikha zhurnalu "Tygodnik Povshekhny" (Tygodnik Powszechny)).» Data zvernennya 27 grudnya, 2019. http://www.newswe. com/index.php?go $=$ Pages\&in $=$ view\&id $=3690$.

Rozenblat, Yevgeniy. «Spaseniye yevreyev Belarusi v gody Kholokosta: nekotoryye teoreticheskiye aspekty temy.» VPravedniki narodov mira Belarusi: zhivyye svidetel'stva Belarusi, sostaviteli Kuz'ma Kozak i dr. Minsk: I. P. Lovinov, 2009.

Shchupak, Ihor. «Mytropolyt Andrey Sheptyts'kyy: osobystist' ta symvol v istoriyi.» Problemy istoriyi Holokostu: naukovyy zhurnal 4 (2007): 88-99.

Shchupak, Igor'. «Otnosheniye ukrainskogo naseleniya Zaporozh'ya k yevreyam vo vremya voyny 1941-1945 gg.» Zaporozhskiye yevreyskiye chteniya 1 (1997): 117-121.

Shchupak, Ihor. «Trahediya yevreyiv Ukrayiny.» V Natsional'ne pytannya $v$ Ukrayini $X X$ - pochatku XXI st.: istorychni narysy, redaktor Valeriy Smoliy, 402-424. Kyyiv: Nika-Tsentr, 2012.

Shchupak, Ihor, red. «Ukrayins'ki ryativnyky yevreyiv pid chas Holokostu.» V Pravednyky narodiv svitu: Dovidnyk, 8-15. Dnipro: Ukrayins'kyy instytut vyvchennya Holokostu «Tkuma», 2016.

Slobodinskii, Dmitro. Poryatonok yevreyiv ukrainntsami uroki Drugoyi Svitovoyi viyni: Disertatsiya na zdobuttya naukovogo stupenya kandidata istorichnih nauk. Kyyiv, 2015.
Snayder, Timoti. Kryvavi zemli: Yevropa pomizh Hitlerom ta Stalinym: monohrafiia. Kyyiv: Hrani-T, 2011.

Sudyn, Danylo. «Natsional'ni mify v suchasniy Ukrayini.» Ukrayina moderna: mizhnarodnyy intelektual'nyy chasopys, 12 hrudnya, 2014. Data zvernennya 22 Hrudnya, 2019. http://uamoderna.com/md/ sudyn-national-myths.

«Te, kto ostalsya v zhivykh. Istoriya Sergeya Sushona.» YouTube Video, 45:54. Rozmishcheno «yadvashemrussian,» 28 Bereznya 2012.https://www. youtube.com/watch? $=\mathrm{rDBnT} 5 \mathrm{yU} \mathbf{-}_{-} \mathrm{M}$.

«Ubili odnosel'chan, pryatavshikh yevreyev. Akt. Khar'kovskaya oblast', Dergachevskiy r-n, s. Semenovka.» V Dokumenty obvinyayut. Kholokost: svidetel'stva Krasnoy Armii. Sostavitel' Fedor Sverdlov. Moskva: [b.i.], 1996.

Umans'kyy, Andriy, upor. Rozsliduvannya Holokostu vid kul' : navchal' nyy posibnyk. PerekladDenys Shatalov. Dnipro: Instytut «Tkuma», 2019.

«Vseukrayins'ka yevreys'ka rada.» Data zvernennya 22 Hrudnya, 2019. http://jadvis.org.ua/component/k2/item/405.

«Zasnovanyy Stivenom Spilberhom Fond Shoa zberihaye 53 tysyachi videosvidchen' pro Holokost.» Data zvernennya 22 Hrudnya, 2019. https:// hromadskeradio.org/programs/zustrichi/zasnovanyy-stivenom-spilbergom-fond-shoa-zberigaye-53-tysyachi-videosvidchen-pro-golokost.

\section{Archives}

Derzhavnyy arkhiv L'vivs'koyi oblasti (DALO).F. R. 7, op. 1, spr. D1230; f. R. 77, op. 1, spr. 309, 366, 502, 504, 574, 592, 654, 661, 735, 758, 759, 791, 800, 847, 851, 904, 1111, 1227, 1258, 1358.

Derzhavnyy arkhiv Zaporiz'koyi oblasti (DAZO). F. R. 1849, op. 1, spr. 1.

Osobystyi arkhiv avtora. 